\title{
Model Pembelajaran Kooperatif pada Pendidikan Agama Islam
}

\author{
DEVI ARISANTI \\ Fakultas Agama Islam (FAI) Universitas Islam Riau (UIR) Pekanbaru \\ Jl. Kaharuddin Nasution No. 113, Perhentian Marpoyan Pekanbaru 28284 \\ e-mail: deviarisanty@gmail.com
}

\begin{abstract}
Abstrak: Pendidikan merupakan wadah untuk memperoleh ilmu yang ditransfer dari guru kepada para siswanya. Dalam pendidikan, istilah model pembelajaran tidak pernah bisa lepas dari setiap kegiatan antara guru dan para siswa dimana model pembelajaran merupakan strategi dalam melaksanakan kegiatan pendidikan. Ketidakpuasan terhadap hasil dari model pembelajaran konvensional menjadikan para pakar pendidikan terus berupaya untuk mengembangkan suatu model pembelajaran yang diharapkan mampu untuk memberikan perbaikan-perbaikan dalam pelaksanaan proses pendidikan. Salah satu model pembelajaran yang dianjurkan yaitu model pembelajaran kooperatif. Model ini menekankan agar para siswa mampu belajar memahami ilmu serta belajar bekerja sama untuk mencapai tujuan pembelajaran tertentu. Pembelajaran kooperatif juga mengajarkan siswa untuk berinteraksi dan berkomunikasi dengan baik antar sesama siswa. Belajar menciptakan hubungan yang baik antara diantara siswa akan melatih siswa untuk terbiasa menciptakan hubungan yang baik diantara manusia. Tujuan ini sangat sesuai dengan ajaran agama islam. Sehingga dengan adanya model pembelajaran kooperatif ini, siswa akan mampu untuk melakukan interaksi yang baik diantara umat manusia baik dalam lingkungan pendidikan di sekolah maupun di lingkungan masyarakatnya.
\end{abstract}

Kata kunci: Model pembelajaran kooperatif, pendidikan agama islam.

\section{PENDAHULUAN}

Model pembelajaran kooperatif adalah salah satu strategi mengajar alternatif yang merupakan perbaikan dari kelemahan pembelajaran konvensional. Bila dibandingkan dengan pembelajaran yang masih bersifat konvensional, model pembelajaran kooperatif memiliki berbagai keunggulan. Menurut MacMillan keunggulan model pembelajaran kooperatif dilihat dari aspek siswa adalah memberi peluang kepada siswa agar mengemukakan dan membahas suatu pandangan, pengalaman, yang diperoleh siswa belajar secara bekerja sama dalam merumuskan kearah pandangan kelompok.

Pembelajaran kooperatif adalah suatu keniscayaan ketika paradigma pembelajaran sudah berubah dari berpusat pada guru (teacher centered) menjadi lebih berpusat pada siswa (student centered). Ini bermakna bahwa peserta didik tidak lagi dianggap sebagai objek pembelajaran, bahkan dia juga 
ikut dalam menentukan perkembangan dirinya (Ramayulis, 2012: 241).

Pendidikan Agama Islam juga memerlukan model pembelajaran kooperatif ini agar para peserta didik lebih memupuk rasa solidaritas antar sesama dan untuk memupuk karakter gotong-royong dan keinginan untuk sukses bersama bukan mementingkan diri sendiri.

Ada banyak alasan yang membuat model pembelajaran kooperatif diterapkan dalam sistem pendidikan saat ini. Menurut Slavin penggunaan model pembelajaran kooperatif ini dapat meningkatkan pencapaian prestasi para siswa dan juga akibatakibat positif lainnya yang dapat mengembangkan hubungan antar kelompok, penerimaan terhadap teman sekelas yang lemah dalam bidang akademik dan meningkatkan rasa harga diri. Pembelajaran kooperatif menumbuhkan kesadaran bahwa siswa perlu berfikir, menyelesaikan masalah dan mengaplikasikan kemampuan dan pengetahuan mereka. Pembelajaran kooperatif merupakan salah satu pembelajaran yang mendorong siswa untuk aktif bertukar pikiran dengan sesamanya dalam memahami suatu materi pembelajaran. Dalam pembelajaran kooperatif, siswa belajar dan bekerja dalam kelompok-kelompok. Belajar kooperatif menekankan pada kerjasama, saling membantu dan berdiskusi bersama dalam menyelesaikan tugas-tugas yang diberikan.

Begitu juga di dalam ajaran Islam ditemukan ayat al-Qur'an yang menganjurkan manusia untuk melakukan kerjasama, firman Allah SWT:

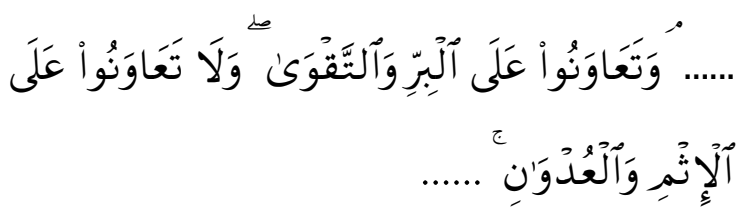

Artinya: "Bertolong-tolonglah kamu dalam kebaikan dan ketakwaan, dan jangan bertolong-tolong dalam dosa dan permusuhan" (QS. Al-Maidah : 2).

Makalah ini akan membahas tentang pengertian dan tujuan pembelajaran kooperatif, teori yang mendasari pembelajaran kooperatif, karakteristik dan prinsip-prinsip pembelajaran kooperatif, unsure-unsur pembelajaran kooperatif, langlahlangkah pembelajaran kooperatif, dan beberapa tipe model pembelajaran kelompok.

\section{PEMBELAJARAN KOOPERATIF}

Pembelajaran kooperatif merupakan suatu strategi dalam proses pembelajaran yang membutuhkan partisipasi dan kerjasama dalam kelompok; dengan kerjasama dapat meningkatkan cara kerja peserta didik menuju lebih baik, dan memupuk sikap tolong menolong dalam beberapa perilaku sosial (Lie, 2004: 27).

Menurut Slavin, pembelajaran kooperatif sebagai lingkungan belajar dimana peserta didik bekerjasama dalam suatu kelompok kecil yang kemampuannya berbeda-beda untuk menyelesaikan tugas-tugas akademik (Slavin, 2011: 4).

Dengan demikian pembelajaran kooperatif tidak sama dengan kerja kelompok secara berkelompok. Tetapi pembelajaran kooperatif lebih dari sekedar belajar kelompok, karena dalam pembelajaran kooperatrif ada tugas yang bersifat kooperatif sehingga memungkinkan terjadinya interaksi secara terbuka dan hubungan yang 
bersifat interdepeciensi efektif diantara anggota kelompok.

Pembelajaran

kooperatif

merupakan suatu pembelajaran yang mengkondisikan peserta didik untuk belajar dalam satu kelimpok kecil dengan tingkat kemampuan yang berbeda. Dalam menyelesaikan tugas kelompok, setiap anggota bekerja sama secara kolaboratif dan membantu untuk memahami suatu materi pembelajaran, memeriksa dan memperbaiki jawaban teman, serta kegiatan lainnya dengan tujuan mencapai hasil belajartertinggi. Kegiatan belajar belum selesai, jika salah satu anggota kelompok belum menguasai materi pembelajaran (Slavin, 2011: 4).

Menurut Anita Lie, pembelajaran kooperatif dapat diartikan sebagai struktur tugas bersama dalam suasana kebersamaan diantara sesama anggota kelompok. Disamping itu cooperative learning juga sering diartikan sebagai motif kerjasama, dimana setiap individu dihadapkan pada preposisi dan pilihan yang harus diikuti apakah memilih bekerja bersama-sama, berkompetisi, atau individualis. Penggunaan model cooperative learning adalah suatu proses yang membutuhkan partisipasi dan kerjasama dalam kelompok. Pembelajaran kooperatif dapat meningkatkan belajar menuju belajar lebih baik, sikap tolong menolong dan beberapa perilaku sosial (Lie, 2004: 12).

\section{Tujuan Pembelajaran Kooperatif}

Tujuan pembelajaran kooperatif berbeda dengan kelompok tradisional yang menerapkan sistem kompetisi, di mana keberhasilan individu diorientasikan pada kegagalan orang lain. Sedangkan tujuan pembelajaran kooperatif adalah menciptakan situasi di mana keberhasilan individu ditentukan atau dipengaruhi oleh keberhasilan kelompoknya.

Arends menyatakan ada tiga tujuan pembelajaran kooperatif, yaitu: (1) Hasil Belajar Akademik. Dalam pembelajaran kooperatif meskipun mencakup beragam tujuan sosial, juga memperbaiki prestasi peserta didik atau tugas-tugas akademik penting lainnya. Pembelajaran kooperatif juga bermanfaat bagi peserta didik yang berprestasi rendah, sedang dan tinggi karena mereka dapat bekerja sama dalam menangani persoalan dengan saran tutur sebaya; (2) Penerimaan Pendapat yang Beraneka Ragam. Tujuan lain model pembelajaran kooperatif adalah penerimaan secara luas dari orang-orang yang berbeda berdasarkan ras, budaya, kelas sosial, kemampuan dan ketidakmampuannya untuk bekerja sama dalam menangani persoalan akademik. Dan melalui struktur penghargaan peserta didik saling menghargai satu sama lain; dan (3) Pengembangan Keterampilan Sosial. Tujuan penting ketiga pembelajaran kooperatif adalah mengajarkan kepada peserta didik keterampilan bekerja sama dan kolaborasi. Keterampilanketerampilan sosial penting dimiliki oleh peserta didik, sebab saat ini banyak anak muda yang masih kurang dalam keterampilan sosial.

Prof. Ramayulis menambahkan tujuan dari pembelajaran kooperatif adalah penghargaan terhadap orang lain. Dengan pembelajaran kooperatif para peserta didik dapat menghargai pendapat orang lain dan saling membetulkan kesalahan secara bersama, mencari jawaban yang paling tepat dan benar dengan mencari sumber-sumber pembelajaran mana saja seperti buku paket, buku-buku yang ada di perpustakaan dan buku-buku pelajaran di internet dan sumber lainnya untuk dijadikan pembantu 
dalam mencari jawaban yang baik dan benar serta untuk memperoleh pemahaman terhadap materi pelajaran yang disediakan dalam silabus (Ramayulis, 2013: 244).

\section{Teori yang Mendasari Pembelajaran Kooperatif}

Ada beberapa teori para ahli yang mendasari pembelajaran kooperatif, dua diantaranya yaitu: (1) Teori Pembelajaran Ausabel. Menurut Ausabel, bahkan subjek yang dipelajari peserta didik mestilah bermakna " (meaning full). Pembelajaran bermakna terjadi apabila peserta didik menghubungkan fenomena baru ke dalam struktur pengetahuan mereka (Sagala, 2004: 88); dan (2) Teori pembelajaran Vygotsky. Dalam teori ini, Vygotsky menjelaskan bahwa ada hubungan secara langsung antara domain kognitif dengan sosio budaya. Kualitas berfikir peserta didik dibina dan dikembangkan di dalam ruangan belajar dalam bentuk kerjasama sesama mereka yang lebih mampu, dibawah bimbingan pendidik (Nurwahyuni, 2007: 24).

\section{Karakteristik Pembelajaran Koope- ratif (Cooperative Learning)}

Model pembelajaran kelompok adalah rangkaian kegiatan belajar yang dilakukan oleh peserta didik dalam kelompok-kelompok tertentu untuk mencapai tujuan pembelajaran yang telah dirumuskan.

Ada empat unsur penting dalam pembelajaran kooperatif (cooperative learning), yaitu: (1) Adanya peserta dalam kelompok. Peserta adalah peserta didik yang melakukan proses pembelajaran dalam setiap kelompok belajar. Pengelompokan peserta didik biasanya ditetapkan berdasarkan beberapa pendekatan, diantaranya pengelompokan yang didasarkan atas minat dan bakat peserta didik, atas latar belakang kemampuan, pengelompokan yang didasarkan atas campuran baik campuran ditinjau dari minat maupun campuran ditinjau dari kemampuan; (2) Adanya aturan kelompok. Aturan kelompok adalah segala sesuatu yang menjadi kesepakatan semua pihak yang terlibat baik peserta didik sebagai peserta didik maupun peserta didik sebagai anggota kelompok. Misalnya aturan tentang pembagian tugas setiap anggota kelompok, waktu dan tempat pelaksanaan dan lain sebagainya; (3) Adanya upaya belajar setiap anggota kelompok. Upaya belajar adalah segala aktivitas peserta didik untuk meningkatkan kemampuannya yang telah dimiliki maupun meningkatkan kemampuan baru,baik kamampuan dalam aspek pengetahuan, sikap, maupun keterampilan. Dalam kelompok antar peserta dapat saling membelajarkan melalui tukar pikiran, pengalaman, maupun gagasan-gagasan; dan (4) Adanya tujuan yang harus dicapai. Aspek tujuan dimaksudkan untuk memberi arah perencanaan, pelaksanaan dan evaluasi. Strategi pembelajaran kooperatif (cooperative learning) mempunyai dua komponen utama, yaitu: pertama, komponen tugas kooperatif (cooperative task) berkaitan dengan hal yang menyebabkan anggota bekerja sama dalam menyelesaikan tugas kelompok; kedua, komponen struktur insentif kooperatif (cooperative incentive structure) merupakan sesuatu yang membangkitkan motivasi individu untuk bekerja sama mencapai tujuan kelompok.

Selain memiliki dampak pembelajaran model pembelajaran kooperatif (cooperative learning) juga memiliki harapan atau dampak lain, yaitu berupa peningkatan prestasi 
belajar peserta didik (student achievement), juga mempunyai dampak pengiring seperti relasi sosial, penerimaan terhadap peserta didik yang dianggap lemah, harga diri, norma akademik, penghargaan terhadap waktu, dan suka memberi pertolongan kepada anggota lain. Pembelajaran kooperatif (cooperative learning) berbeda dengan model yang lain. Perbedaan tersebut dapat dilihat dari proses kerja sama dalam kelompok. Adanya kerja sama kelompok inilah yang menjadi ciri khas dari pembelajaran kooperatif (cooperative learning). Slavin, Abrani, dan Chambers berpendapat bahwa belajar melalui kooperatif dapat dijelaskan dari beberapa perspektif, yaitu: (a) Perspektif sosial, artinya bahwa melalui kooperatif setiap peserta didik akan saling membantu dalam belajar karena mereka menginginkan semua anggota kelompok memperoleh keberhasilan (Sanjaya, 2006: 107); (b) Perspektif motivasi, artinya bahwa penghargaan yang diberikan kepada kelompok memungkinkan setiap anggota kelompok akan saling membantu. Dengan demikian, keberhasilan individu pada dasarnya adalah keberhasilan kelompok. Hal semacam ini akan mendorong setiap anggota kelompok untuk memperjuangkan keberhasilan kelompoknya; dan (c) Perspektif perkembangan kognitif, artinya bahwa dengan adanya interaksi antara anggota kelompok dapat mengembangkan prestasi peserta didik untuk berpikir mengolah berbagai informasi. Elaborasi kognitif artinya bahwa setiap peserta didik akan berusaha untuk memahami dan menimba informasi untuk menambah pengetahuan kognitifnya.

Dengan demikian, karakteristik strategi pembelajaran kooperatif (cooperative learning) dapat dijelaskan sebagai berikut: Pertama,
Pembelajarannya secara tim. Pembelajaran kooperatif (cooperative learning) adalah pembelajaran secara tim, di mana tim merupakan tempat mencapai tujuan. Oleh karena itu, tim harus mampu membuat setiap peserta didik belajar, semua anggota tim (anggota kelompok) harus saling membantu untuk mencapai tujuan pembelajaran. Dalam pembelajaran kooperatif (cooperative learning) setiap kelompok bersifat heterogen. Artinya kelompok terdiri atas anggota yang memiliki kemampuan akademik, jenis kelamin, dan latar belakang yang berbeda. Hal ini dimaksudkan agar setiap anggota kelompok dapat saling memberikan pengalaman, saling memberi dan menerima, sehingga diharapkan setiap anggota kelompok dapat saling memberikan kontribusi terhadap keberhasilan kelompok.

Kedua, Didasarkan pada manajemen kooperatif. Dalam pembelajaran kooperatif (cooperative learning) manajemen mempunyai empat fungsi pokok, yaitu: a) fungsi perencanaan menunjukkan bahwa pembelajaran kooperatif (cooperative learning) memerlukan perencanaan yang matang agar proses pembelajaran berjalan secara efektif misalnya tujuan apa yang harus dicapai, bagaimana cara mencapaiannya, apa yang harus digunakan untuk mencapai tujuan itu dan lain sebagainya; b) fungsi pelaksanaan menunjukan bahwa pembelajaran kooperatif (cooperative learning) harus dilaksanakan sesuai dengan perencanaan, melalui langkahlangkah pembelajaran yang telah ditentukan termasuk ketentuanketentuan yang sudah disepakati bersama; c) fungsi organisasi menunjukan bahwa pembelajaran kooperatif (cooperative learning) adalah pekerjaan bersama antar setiap anggota kelompok, oleh sebab itu perlu diatur tugas dan 
tanggung jawab setiap anggota kelompok; d) fungsi kontrol menunjukan bahwa dalam pembelajaran kooperatif (cooperative learning) perlu ditentukan kriteria keberhasilan melalui tes maupun non tes.

Ketiga, kemampuan untuk bekerja sama. Prinsip bekerja sama perlu ditekankan dalam proses pembelajaran kooperatif (cooperative learning), karena keberhasilan kooperatif ditentukan oleh keberhasilan secara kelompok. Setiap anggota kelompok bukan saja harus diatur tugas dan tanggung jawab masing-masing, akan tetapi juga ditanamkan perlunya saling membantu. Misalnya, yang pintar perlu membantu yang kurang pintar.

Keempat, keterampilan bekerja sama. Kemampuan untuk bekerja sama itu kemudian dipraktekkan melalui aktivitas dan kegiatan yang tergambarkan dalam keterampilan bekerja sama. Dengan demikian, peserta didik perlu didorong untuk mau dan sanggup berinteraksi dan berkomunikasi dengan anggota lain. Peserta didik perlu dibantu mengatasi berbagai hambatan dalam berinteraksi dan berkomunikasi, sehingga setiap peserta didik dapat menyampaikan ide, mengemukakan pendapat, dan memberikan kontribusi kepada keberhasilan kelompok (Sanjaya, 2012: 244-246).

Menurut Arends yang dikutip Masnur Muslich ada 6 fase atau langkah utama dalam pembelajaran kooperatif, fase atau langkah-langkah tersebut yaitu: (a) Fase 1: Menyampaikan tujuan dan memotivasi peserta didik. Guru menyampaikan semua tujuan pembelajaran yang ingin dicapai pada pelajaran tersebut dan memotivasi peserta didik belajar; (b) Fase 2: Menyajikan Informasi. Guru menyajikan informasi kepada peserta didik, baik dengan peragaan (demonstrasi) atau teks; (c) Fase 3: Mengorganisasikan peserta didik ke dalam kelompokkelompok belajar. Guru menjelaskan kepada peserta didik bagaimana caranya membentuk kelompok belajar dan membantu setiap kelompok agar melakukan perubahan yang efisien; (d) Fase 4: Membantu kerja kelompok dalam belajar. Guru membimbing kelompok- kelompok belajar pada saat mereka mengerjakan tugas; (e) Fase 5: Evaluasi. Guru mengevaluasi hasil belajar tentang materi yang telah dipelajari atau masing kelompok mempresentasikan hasil kerja mereka; dan (f) Fase 6: Memberikan penghargaan. Guru memberikan caracara untuk menghargai, baik upaya maupun hasil belajar individu dan kelompok (Muslich, 2007: 230).

\section{Unsur-unsur Pembelajaran Kooperatif Menurut Roger dan David Johnson} ada lima unsur dasar dalam pembelajaran kooperatif, yaitu sebagai berikut: Pertama, saling Ketergantungan Positif. Saling ketergantungan positif menuntut adanya interaksi promotif yang memungkinkan sesama siswa saling memberikan motivasi untuk meraih hasil belajar yang optimal. Tiap siswa tergantung pada anggota lainnya karena tiap siswa mendapat materi yang berbeda atau tugas yang berbeda, oleh karena itu siswa satu dengan lainnya saling membutuhkan karena jika ada siswa yang tidak dapat mengerjakan tugas tersebut maka tugas kelompoknya tidak dapat diselesaikan.

$$
\text { Kedua, tanggung Jawab }
$$

Perseorangan. Pembelajaran kooperatif juga ditujukan untuk mengetahui penguasaan siswa terhadap materi pelajaran secara individual. Hasil penilaian individual tersebut selanjutnya disampaikan guru kepada kelompok agar semua kelompok dapat 
mengetahui siapa anggota kelompok yang memerlukan bantuan dan siapa anggota kelompok yang dapat memberikan bantuan. Karena tiap siswa mendapat tugas yang berbeda secara otomatis siswa tersebut harus mempunyai tanggung jawab untuk mengerjakan tugas tersebut karena tugas setiap anggota kelompok mempunyai tugas yang berbeda sesuai dengan kemampuannya yang dimiliki setiap individu.

Ketiga, Interaksi Tatap Muka. Interaksi tatap muka menuntut para siswa dalam kelompok dapat saling bertatap muka sehingga mereka dapat melalukan dialog, tidak hanya dengan guru, tetapi juga dengan sesama siswa. Interaksi semacam ini memungkinkan siswa dapat sa- ling menjadi sumber belajar sehingga sumber belajar lebih bervariasi dan ini juga akan lebih memudahkan siswa dalam belajar. Adanya tatap muka, maka siswa yang kurang memiliki kemampuan harus dibantu oleh siswa yang lebih mampu mengerjakan tugas individu dalam kelompok tersebut, agar tugas kelompoknya dapat terselesaikan.

Keempat, komunikasi antar Anggota Kelompok. Dalam pembelajaran kooperatif keterampilan sosial seperti tenggang rasa, sikap sopan terhadap teman, mengkritik ide dan bukan mengkritik teman, berani mempertahan pikiran logis, tidak mendominasi orang lain, mandiri dan berbagai sifat lain yang bermanfaat dalam menjalin hubungan antar pribadi sengaja diajarkan dalam pembelajaran kooperatif ini. Unsur ini juga menghendaki agar para siswa dibekali dengan berbagai keterampilan berkomunikasi.Sebelum menugaskan siswa dalam kelompok, guru perlu mengajarkan cara-cara berkomunikasi, karena tidak semua siswa mempuanyai keahlian mendengarkan dan berbicara. Keberhasilan suatu kelompok tergantung pada kesediaan para anggotanya untuk saling mendengarkan dan kemampuan mereka untuk mengutarakan pendapat mereka. Adakalanya siswa perlu diberitahu secara jelas mengenai cara menyanggah pendapat orang lain tanpa harus menyinggung perasaan orang lain.

Kelima, Evaluasi Proses Kelompok. Pengajar perlu menjadwalkan waktu khusus bagi kelompok untuk mengevaluasi proses kerja kelompok dan hasil kerja sama mereka agar selanjutnya bisa bekerja sama dengan lebih efektif. Waktu evaluasi ini tidak perlu diadakan setiap kali ada kerja kelompok, tetapi bisa diadakan selang beberapa waktu setelah beberapa pembelajar terlibat dalam kegiatan pembelajaran cooperative learning (Suprijono, 2013: 58-63).

\section{Tipe Model Pembelajaran Kelompok}

Ada beberapa tipe model pembelajaran kelompok, diantaranya yaitu STAD, struktural, jigsaw dan investigasi kelompok.

\section{Tipe Student Team Achievement Division (STAD)}

STAD pertama kali dikembangkan oleh Robert Slavin dan teman-temannya dari Universitas John Hopkin. Menurut Slavin model STAD ini merupakan variasi model pembelajaran kooperatif yang paling banyak diteliti. Model ini juga sangat mudah diadaptasi, dan telah digunakan dalam berbagai mata pelajaran.

Untuk tipe STAD ini siswa dikelompokkan secara heterogen kemudian siswa yang pandai menjelaskan kepada anggota lain sampai mengerti. Adapun langkah- langkahnya, yaitu: (1) Membentuk kelompok yang anggotanya 4 orang secara heterogen 
(campuran menurut prestasi, jenis kelamin, suku, dll); (2) Guru menyajikan pelajaran; (3) Guru memberi tugas kepada kelompok untuk dikerjakan oleh anggota kelompok. Anggota yang lebih paham menjelaskan kepada anggota lainnya sampai semua anggota dalam kelompok itu mengerti; (4) Guru memberi kuis / pertanyaan kepada seluruh siswa. Pada saat menjawab kuis tidak boleh saling membantu; Memberi evaluasi; dan (6) Penutup.

Kelebihan dari tipe ini yaitu seluruh siswa menjadi lebih siap dan melatih kerjasama dengan baik. Sedangkan kelemahannya adalah apabila semua anggota kelompok mengalami kesulitan.

\section{Tipe Pendekatan Struktural}

Pendekatan ini dikembangkan oleh Spenser dan Miguel Kagan. Salah satu bentuk pendekatan struktural yang sering digunakan adalah "think pair share", yang dikembangkan oleh Frank Lyman dan kawan-kawan dari Universitas Maryland. Ia mampu mengubah asumsi bahwa metode resitasi dan diskusi perlu diselenggarakan dalam setting kelompok kelas secara keseluruhan.

berikut:

Langkah-langkahnya sebagai

Langkah pertama berpikir (think), yaitu guru memberikan pertanyaan atau sebuah isu yang berhubungan dengan materi pelajaran kemudian siswa diberi waktu satu menit untuk berpikir sendiri mengenai jawaban dan isu tersebut.

Langka kedua berpasangan (pair), yaitu siswa diminta untuk berpasangan dan mendiskusikan mengenai apa yang telah dipikirkan selama empat sampai lima menit. Interaksi yang dibangun diharapakan dapat menghasilkan jawaban bersama atas sebuah pertanyaan, atau penyampaian idebersama jika suatu isu khusus telah diidentifikasi.

Langkah terakhir adalah berbagi (sharing) dimana guru meminta pasangan-pasangan tersebut untuk berbagi atau bekerjasama dengan kelas secara keseluruhan mengenai apa yang telah mereka diskusikan.

\section{Tipe Jigsaw}

Jigsaw pertama kali dikembangkan oleh Elliot Aronson di Universitas Texas. Pada dasarnya, dalam tipe ini guru membagi satuan informasi yang besar menjadi komponen-komponen lebih kecil. Selanjutnya guru membagi siswa ke dalam kelompok belajar kooperatif yang terdiri dari empat orang siswa sehingga setiap anggota bertanggungjawab terhadap penguasaan setiap komponen/subtopik yang ditugaskan guru dengan sebaik-baiknya. Siswa dari masing-masing kelompok yang bertanggung-jawab terhadap subtopik yang sama membentuk kelompok lagi yang terdiri dari yang terdiri dari dua atau tiga orang.

Siswa-siswa ini bekerja sama
untuk menyelesaikan
kooperatifnya dalam: a) belajar dan menjadi ahli dalam subtopik bagiannya; b) merencanakan bagaimana mengajarkan subtopik bagiannya kepada anggota kelompoknya semula. Setelah itu siswa tersebut kembali lagi ke kelompok masing-masing sebagai "ahli" dalam supbtopiknya dan mengajarkan informasi penting dalam subtopik tersebut kepada temannya. Ahli dalam subtopik lainnya juga bertindak serupa. Sehingga seluruh siswa bertanggung jawab untuk menunjukkan penguasaannya terhadap seluruh materi yang ditugaskan oleh guru. Dengan demikian, setiap siswa dalam kelompok harus menguasai topik secara keseluruhan. 


\section{Tipe Investigasi Kelompok (Group Investigation)}

Tipe ini pertama kali dikembangkan oleh Herbert Thelen kemudian diperluas dan diperbaiki oleh Sharan dan kawan-kawan dari Universitas Tel Aviv. Tipe ini menuntut para siswa untuk memiliki kemampuan yang baik dalam berkomunikasi maupun dalam ketrampilan proses kelompok (group process skills). Para guru yang menggunakan tipe investigasi kelompok umumnya membagi kelas menjadi beberapa kelompok yang beranggotakan 5 hingga 6 siswa dengan karakteristik yang heterogen. Pembagian kelompok dapat juga didasarkan atas kesenangan berteman atau kesamaan minat terhadap suatu topik tertentu. Para siswa memilih topik yang ingin dipelajari, mengikuti investigasi mendalam terhadap berbagai subtopik yang telah dipilih, kemudian menyiapkan dan menyajikan suatu laporan di depan kelas secara keseluruhan. Adapun deskripsi mengenai langkah-langkah metode investigasi kelompok dapat dikemukakan sebagai berikut: (a) Seleksi topik. Para siswa memilih berbagai subtopik dalam suatu wilayah masalah umum yang biasanya digambarkan lebih dahulu oleh guru. Para siswa selanjutnya diorganisasikan menjadi kelompok-kelompok yang berorientasi pada tugas (task oriented groups) yang beranggotakan 2 hingga 6 orang. Komposisi kelompok heterogen baik dalam jenis kelamin, etnik maupun kemampuan akademik; (b) Merenca- nakan kerjasama. Para siswa beserta guru merencanakan berbagai prosedur belajar khusus, tugas dan tujuan umum yang konsisten dengan berbagai topik dan subtopik yang telah dipilih dari langkah a di atas; (c) Implementasi.

Para siswa melaksanakan rencana yang telah dirumuskan pada langkah $b$ diatas. Pembelajaran harus melibatkan berbagai aktivitas dan ketrampilan dengan variasi yang luas dan mendorong para siswa untuk menggunakan berbagai sumber baik yang terdapat di dalam maupun di luar sekolah. Guru secara terus-menerus mengikuti kemajuan tiap kelompok dan memberikan bantuan jika diperlukan; (d) Analisis dan sintesis. Para siswa menganalisis dan mensintesis berbagai informasi yang diperoleh pada langkah c dan merencanakan agar dapat diringkaskan dalam suatu penyajian yang menarik di depan kelas; (e) Penyajian hasil akhir. Semua kelompok menyajikan suatu presentasi yang menarik dari berbagai topik yang telah dipelajari agar semua siswa dalam kelas saling terlibat dan mencapai suatu perspektif yang luas mengenai topik tersebut. Presentasi kelompok dikoordinir oleh guru; (f) Evaluasi Guru beserta siswa melakukan evaluasi mengenai kontribusi tiap kelompok terhadap pekerjaan kelas sebagai suatu keseluruhan. Evaluasi dapat mencakup tiap siswa secara individu atau kelompok, atau keduanya (Rusman, 2013: 213-223 \& Gunawan, 2013: 241244). 
Tabel 01.Perbandingan Karakteristik Model Pembelajaran Kooperatif (Rusman, 2013: 227)

\begin{tabular}{|c|c|c|c|c|}
\hline & STAD & JIGSAW & $\begin{array}{l}\text { INVESTIGASI } \\
\text { KELOMPOK }\end{array}$ & STRUKTURAL \\
\hline $\begin{array}{l}\text { Tujuan } \\
\text { Kognitif }\end{array}$ & $\begin{array}{l}\text { Informasi } \\
\text { akademik } \\
\text { sederhana }\end{array}$ & $\begin{array}{l}\text { Informasi } \\
\text { akademik } \\
\text { sederhana }\end{array}$ & $\begin{array}{l}\text { Informasi akade- } \\
\text { mik tingkat tinggi } \\
\text { dan keterampilan } \\
\text { inquiry }\end{array}$ & $\begin{array}{l}\text { Informasi } \\
\text { akademik } \\
\text { sederhana }\end{array}$ \\
\hline $\begin{array}{c}\text { Tujuan } \\
\text { Sosial }\end{array}$ & $\begin{array}{l}\text { Kerja kelompok } \\
\text { dan kerja sama }\end{array}$ & $\begin{array}{l}\text { Kerja kelom- } \\
\text { pok dan } \\
\text { kerja sama }\end{array}$ & $\begin{array}{l}\text { Kerjasama dalam } \\
\text { kelompok } \\
\text { kompleks }\end{array}$ & $\begin{array}{l}\text { Keterampilan } \\
\text { kelompok dan } \\
\text { keterampilan sosial }\end{array}$ \\
\hline $\begin{array}{l}\text { Struktur } \\
\text { Tim }\end{array}$ & $\begin{array}{l}\text { Kelompok } \\
\text { belajar } \\
\text { heterogen } \\
\text { dengan 4-5 } \\
\text { orang anggota } \\
\end{array}$ & $\begin{array}{l}\text { Kerja } \\
\text { kelompok } \\
\text { dan kerja } \\
\text { sama }\end{array}$ & $\begin{array}{l}\text { Kelompok belajar } \\
\text { dengan 5-6 } \\
\text { anggota homogen }\end{array}$ & $\begin{array}{l}\text { Bervariasi berdua, } \\
\text { bertiga kelompok } \\
\text { dengan 4-6 anggota }\end{array}$ \\
\hline $\begin{array}{l}\text { Pemilihan } \\
\text { Topik } \\
\text { pelajaran } \\
\end{array}$ & Biasanya guru & $\begin{array}{l}\text { Biasanya } \\
\text { guru }\end{array}$ & Biasanya siswa & Biasanya guru \\
\hline \multirow[t]{2}{*}{$\begin{array}{l}\text { Tugas } \\
\text { utama }\end{array}$} & $\begin{array}{l}\text { Siswa dapat } \\
\text { menggunakan } \\
\text { lembar } \\
\text { kegiatan dan }\end{array}$ & $\begin{array}{l}\text { Siswa } \\
\text { mempelajari } \\
\text { materi } \\
\text { dalam } \\
\text { kelompok } \\
\text { ahli }\end{array}$ & $\begin{array}{l}\text { Siswa } \\
\text { menyelesaikan } \\
\text { inquiry kompleks }\end{array}$ & $\begin{array}{l}\text { Siswa mengerjakan } \\
\text { tugas-tugas yang } \\
\text { diberikan }\end{array}$ \\
\hline & $\begin{array}{l}\text { Siswa saling } \\
\text { membantu } \\
\text { untuk } \\
\text { menuntaskan } \\
\text { materi } \\
\text { belajarnya }\end{array}$ & $\begin{array}{l}\text { Kemudian } \\
\text { membantu } \\
\text { anggota } \\
\text { kelompok } \\
\text { "asal" } \\
\text { mempelajari } \\
\text { materi itu }\end{array}$ & & Sosial dan kognitif \\
\hline Penilaian & Tes mingguan & $\begin{array}{l}\text { Bervariasi, } \\
\text { dapat } \\
\text { berupa tes } \\
\text { mingguan }\end{array}$ & $\begin{array}{l}\text { Menyelesaikan } \\
\text { proyek dan } \\
\text { menulis laporan, } \\
\text { dapat menggu- } \\
\text { nakan tes essay }\end{array}$ & Bervariasi \\
\hline Pengakuan & $\begin{array}{l}\text { Lembar } \\
\text { pengetahuan } \\
\text { dan publikasi } \\
\text { lainnya }\end{array}$ & $\begin{array}{l}\text { Publikasi } \\
\text { lain }\end{array}$ & $\begin{array}{l}\text { Lembar } \\
\text { penetahuan dan } \\
\text { publikasi lain }\end{array}$ & Bervariasi \\
\hline
\end{tabular}

\section{Keunggulan dan Kelemahan Pembelajaran Kooperatif}

Adapun keunggulan pembelajaran kooperatif diantaranya: (a) Siswa dapat menambah kemampuan dalam berpikir sendiri, menemukan informasi dari berbagai sumber, dan belajar dari siswa lain; (b) Siswa dapat mengembangkan kemampuan mengungkapkan ide atau gagasan dengan kata-kata secara verbal 
dan membandingkannya dengan ide-ide orang lain; (c) Siswa dapat belajar untuk respek pada orang lain dan menyadari akan segala keterbatasannya serta menerima segala perbedaan; (d) Model pembelajaran ini dapat membantu memberdayakan setiap siswa untuk lebih bertanggung jawab dalam belajar; (e) Siswa dapat meningkatkan prestasi akademik sekaligus kemampuan sosial, termasuk mengembangkan rasa harga diri, hubungan interpersonal yang positif dengan orang lain, mengembangkan keterampilan memanage waktu, dan sikap positif terhadap sekolah; (f) Siswa dapat mengembangkan kemampuannya untuk menguji ide dan pemahamannya sendiri, serta menerima umpan balik. Dan juga siswa dapat berpraktik memecahkan masalah tanpa takut membuat kesalahan, karena keputusan yang dibuat adalah tanggung jawab kelompoknya; (g) Model pembelajaran ini dapat meningkatkan kemampuan siswa dalam menggunakan informasi; dan (h) Interaksi selama kooperatif berlangsung dapat meningkatkan motivasi dan memberikan rangsangan untuk berpikir. Hal ini berguna untuk proses pendidikan jangka panjang.

Sedangkan kelemahan dari pembelajaran kooperatif diantaranya: (a) Untuk memahami dan mengerti filosofis pembelajaran kooperatif memang membutuhkaan waktu. Sangat tidak rasional kalau kita mengharapkan secara otomatis siswa dapat mengerti dan memahami filsafat cooperative learning. Untuk siswa yang dianggap memiliki kelebihan, contohnya, mereka akan merasa terhambat oleh siswa yang dianggap kurang memiliki kemampuan. Akibatnya, keadaan semacam ini dapat mengganggu iklim kerjasama dalam kelompok; (b) Ciri utama dari pembelajaran kooperatif adalah bahwa siswa saling membelajarkan, oleh karena itu, jika tanpa peer teaching yang efektif, maka dibandingkan dengaan pengajaran langsung dari guru, bisa terjadi cara belajar yang demikian apa yang seharusnya dipelajari dan dipahami tidak pernah dicapai oleh siswa; (c) Penilaian yang diberikan dalam pembelajaran kooperatif didasarkan kepada hasil kerja kelompok. Namun demikian, guru perlu menyadari, bahwa sebenarnya hasil atau prestasi yang diharapkan adalah prestasi setiap individu siswa; (d) Keberhasilan pembelajaran kooperatif dalam upaya mengembangkan kesadaran berkelompok memerlukan periode waktu yang cukup panjang. Dan hal ini tidak mungkin dapat tercapai hanya dengan satu kali penerapan saja; dan (e) Walaupun kemampuan bekerja sama merupakan kemampuan yang sangat penting untuk siswa, akan tetapi banyak aktivitas dalam kehidupan yang hanya didasarkan kepada kemampuan secara individual. Oleh karena itu idealnya melalui pembelajaran kooperatif selain siswa belajar bekerja sama, siswa juga harus belajar bagaimana membangun kepercayaan diri. Untuk mencapai kedua hal itu dalam pembelajaran kooperatif memang bukan pekerjaan yang mudah (Sanjaya, 2012: 249-251).

\section{SIMPULAN}

Pembelajaran kooperatif merupakan salah satu model pembelajaran yang lebih memungkinkan siswa untuk aktif dan guru berperan sebagai fasilitator. Model pembelajaran ini lebih banyak mengarah kepada belajar kelompok. Namun tidak bisa disamakan dengan belajar kelompok seperti yang dipahami oleh sebagian orang. Dalam pembelajaran kooperatif proses 
pembelajaran tidak harus belajar dari guru kepada siswa. Siswa dapat saling membelajarkan sesama siswa lainnya. Bahkan pembelajaran oleh rekan sebaya (peer teaching) lebih efektif dari pembelajaran oleh guru.

Pembelajaran kooperatif juga mengajarkan siswa untuk berinteraksi dan berkomunikasi dengan baik antar sesama siswa.

\section{DAFTAR RUJUKAN}

Gunawan, Heri. 2013. Kurikulum dan Pembelajaran Pendidikan Agama Islam. Bandung: Alfabeta.

Lie, Anita. 2004. Cooperative Learning. Jakarta : Grasindo.

Muslich, Masnur. 2007. KTSP: Pembelajaran Berbasis Kompetensi dan Kontekstual. Jakarta: Bumi Aksara.

Nurwahyuni, Esa. 2007. Teori Belajar dan Pembelajaran. Yogyakarta: Anzul Media.
Ramayulis. 2012. Metodologi Pendidikan Agama Islam. Jakarta: Kalam Mulia.

Rusman. 2013. Model-model Pembelajaran, Mengembangkan Profesionalisme Guru. Jakarta: PT. Raja Grafindo Persada.

Sagala, Syaiful. 2004. Konsep dan Makna Pembelajaran. Bandung: Alfabeta.

Sanjaya, Wina. 2006. Pembelajaran Dalam Implementasi Kurikulum Berbasis Kompetensi. Jakarta:Prenada Media Group.

Sanjaya, Wina. 2012. Strategi Pembelajaran Berorientasi Standar Proses Pendidikan. Jakarta: Prenada Media Group.

Slavin, Robert E., 2011. Cooperative Learning, Teori, Riset dan Praktik. Bandung: Nusa Media.

Suprijono, Agus. 2013. Cooperative Learning, Teori dan Aplikasi PAIKEM. Yogyakarta: Pustaka Pelajar. 